\title{
OPTIMIZATION OF THE EPITHERMAL NEUTRON BEAM FOR BORON NEUTRON CAPTURE THERAPY AT THE BROOKHAVEN MEDICAL RESEARCH REACTOR
}

\author{
Jih-Perng Hu, David C. Rorer, Richard N. Reciniello, Norman E. Holden \\ Brookhaven National Laboratory \\ Upton, New York, 11973-5000, USA
}

E-mail: hu1@bnl.gov

\begin{abstract}
Clinical trials of Boron Neutron Capture Therapy for patients with malignant brain tumor had been carried out for half a decade, using an epithermal neutron beam at the Brookhaven's Medical Reactor. The decision to permanently close this reactor in 2000 cut short the efforts to implement a new conceptual design to optimize this beam in preparation for use with possible new protocols. Details of the conceptual design to produce a higher intensity, more forward-directed neutron beam with less contamination from gamma rays, fast and thermal neutrons are presented here for their potential applicability to other reactor facilities. Monte Carlo calculations were used to predict the flux and absorbed dose produced by the proposed design. The results were benchmarked by the dose rate and flux measurements taken at the facility then in use.
\end{abstract}

\section{Introduction}

The Brookhaven Medical Research Reactor (BMRR [1]) was a light water cooled and moderated, graphite reflected reactor, which was operated on demand at a power level up to 3 MW for medical and biological research. It was permanently closed down at the end of December of the year 2000. The BMRR had two separate treatment rooms, featuring an epithermal neutron beam at the Epithermal Neutron Irradiation Facility (ENIF) and a thermal neutron beam at the Thermal Neutron Irradiation Facility (TNIF). Prior to the closure of the BMRR, the primary use of the epithermal beam was to perform Boron Neutron Capture Therapy (BNCT) research [2] in the form of clinical trials on patients with malignant brain tumors (glioblastoma multiforme).

BNCT is a binary treatment that consists of a drig containing boron that is delivered preferentially to the tumor (rather than normal cells), and the subsequent irradiation of both tumor and normal cells with thermal neutrons. This treatment destroys the cells containing boron, while sparing those that are boron-free. The high-energy alpha-particles and ${ }^{7} \mathrm{Li}$ nuclei released by the neutron capture reaction in boron have a very short range - of the order of a cell diameter - and will destroy only those targeted cells near the boron. With the drugs available at the time, delivery of the boron to tumor cells was not ideal. Some boron was taken up by normal brain cells, while some tumor cells apparently did not absorb the drug at all. Drug absorption by tumor cells to normal cells was 3.5 to 1 . Research has continued on the development of better boron compounds and improvement of their delivery solely to the targeted tumor cells.

If a pure thermal neutron beam was to be used, most of the neutrons would be absorbed before reaching the tumor (which typically is located up to $6 \mathrm{~cm}$ inside the cranium), and the patient would suffer radiation burns to the scalp. Instead, an epithermal neutron beam was directed at the patient's head. As the epithermal neutrons penetrate the cranium and begin to traverse the brain, 
they are moderated by the hydrogen they encounter, quickly slowing down and losing their original directionality in the elastic scattering process. The ensuing "cloud" of thermal neutrons then interacts with the boron to deliver a lethal dose to the tumor cells deep within the brain. Efforts to improve the neutron beam were focused on developing higher-intensity epithermal beams that are better collimated, more forward-directed, and uncontaminated by thermal neutrons and gamma-rays that could deliver unwanted radiation to the patient.

At the BMRR, the epithermal neutron beam was upgraded by installing layers of $\mathrm{Al}^{-} \mathrm{Al}_{2} \mathrm{O}_{3}$ in the beam shutter aperture. The reactor core loading was improved by replacing heavily-burned fuel elements and previously vacant positions with fresh fuel elements, to charge the core with 32 fuel elements. The most heavily loaded fuel elements were placed in a row facing the epithermal beam port. This resulted in a 50\% increase in epithermal beam intensity at the irradiation port while the fast-neutron and gamma dose rates increased only $33 \%$ and $25 \%$, respectively. This improved epithermal neutron beam had been used in clinical trials of BNCT for 53 patients.

\section{BMRR Beam Lines}

The BMRR was built in 1959 to perform boron neutron capture therapy (BNCT). The BMRR was designed to operate critically with as few as 17 or as many as $\mathbf{3 2}$ fuel elements. These fuel elements were enriched to $>90 \%$ in ${ }^{235} \mathrm{U}$, and there were four stainless steel control rods containing $1.5 \%$ natural boron. These fuel and control rods were supported in a grid plate, where empty spaces in the grid plate when less than 32 fuel elements were in use, were filled with graphite dummy elements. This core was cooled and moderated by natural water $\left(\mathrm{H}_{2} \mathrm{O}\right)$ inside a 61 $\mathrm{cm}$ diameter cylindrical aluminum vessel. A graphite reflector $(260 \mathrm{~cm}$ by $150 \mathrm{~cm}$ by $180 \mathrm{~cm})$, a neutron shield of $\mathrm{B}_{4} \mathrm{C}$ and borel ${ }^{\mathrm{TM}}$, a thermal shield of laminated steel and a biological shield of dense concrete with iron pellets $\left(4.52 \mathrm{gm} / \mathrm{cm}^{3}\right)$, surrounded the aluminum tank.

Housed in an 18.3-meter diameter gas tight confinement building, the reactor operated routinely at power levels up to $3 \mathrm{MW}$. The TNIF had a thermal neutron beam and the ENIF had an epithermal neutron beam, each separated from the core by a movable shutter, which controlled the availability of these radiation beams. The beam paths had bismuth blocks to absorb a large fraction of core gamma rays. Polonium daughter products resulting from neutron capture in bismuth were enveloped by coating the bismuth with a metal spray of pure magnesium, $0.12 \mathrm{~mm}$ thick. $\mathrm{A} 12 \mathrm{~cm}$ tank designed to fill with $\mathrm{H}_{2} \mathrm{O}$ or $\mathrm{D}_{2} \mathrm{O}$ to alter the beam spectrim to meet experimental needs was located after the bismuth blocks and before the shutter. For the epithermal neutron beam, this tank was empty (air).

The shutter casing was $2 \mathrm{~cm}$ thick steel and surrounded by high density concrete with steel pellets. In the shutter there were parallel $\mathrm{Al}-\mathrm{Al}_{2} \mathrm{O}_{3}$ slabs in $\mathrm{Al}$-boxes with cadmium, $0.2 \mathrm{~mm}$ thick, between the box sections and another bismuth block, $12 \mathrm{~cm}$ thick, to reduce unwanted thermal neutrons and gamma rays, respectively. The use of $\mathrm{Al}$ and $\mathrm{Al}_{2} \mathrm{O}_{3}$ in a 1 to 4 ratio produced a neutron beam within a narrow energy band of $0.4 \mathrm{eV}-10 \mathrm{keV}$ range. The beam's directionality was improved by a tapered opening with aluminum side plates $2.5 \mathrm{~cm}$ thick and borel ${ }^{\mathrm{TM}}$ cover sheets $0.6 \mathrm{~cm}$ thick, which gradually scatter outbound neutrons back to the axial beam trajectory. In the ENIF around the shutter, there was a shield wall of lead bricks, $8 \mathrm{~cm}$ thick and ${ }^{6} \mathrm{Li}$-enriched $(>90 \%)$ polyethylene slabs, which was $2.5 \mathrm{~cm}$ thick to eliminate stray neutrons around the shutter and secondary gamma rays from the dense concrete. The outer surface of this shield was the inner surface of the ENIF and had an opening port of $25 \mathrm{by} 25 \mathrm{~cm}^{2}$ to allow the beam to pass through.

To enhance beam focusing during patient treatment, there was a ${ }^{6} \mathrm{Li}$-poly collimator attached to the shutter port. This collimator was a $15 \mathrm{~cm}$ long tapered cone with a $20 \mathrm{~cm}$ diameter opening at the core side and a $12 \mathrm{~cm}$ diameter opening at the treatment room side. This describes the status of the epithermal beam line at the time of the last BNCT patient treatment in the year 2000. 


\section{Computations}

To optimize the epithermal neutron beam by the reconfiguration of the BMRR core, the shutter assembly and the beam irradiation port, a computational technique and an experimental method to validate these computations was required. We used the Monte Carlo based code, MCNP-4B2 [3] to calculate the neutron and gamma-ray fluxes and absorbed doses, while measurements of the fluxes and doses at the core-shutter interface and at the irradiation port were made using gold foils and thermoluminescent dosimeters (TLD). The MCNP code is a generalpurpose Fortran-compiled software package, which can be utilized to model any single particle motion or coupled neutron-photon-electron transport in a three-dimensional geometry consisting of different material regions. We used continuous cross sections for neutron and photon transport and reaction rate calculations and appropriate thermal neutron scattering function, $S_{\alpha \beta}$, to treat neutron interactions with light materials such as $\mathrm{H}_{2} \mathrm{O}, \mathrm{D}_{2} \mathrm{O}$, graphite and polyethylene in the MCNP package. To track particle histories better starting from different source locations, a newer version of the program, MCNP-4C, was used allowing the data processing to be performed on a parallel computing platform. The continuous run option increased the particle history and reduced the tally's statistical uncertainty.

The horizontal mid-plane of the BMRR epithermal beam line extended from the center core to the irradiation port is depicted in Figure 1. For efficiency, the heterogeneous reactor core with fuel elements, control rods, water coolant, graphite moderator, and aluminum fillers was replaced by a homogeneous cylinder with $\mathrm{U}, \mathrm{H}, \mathrm{O}, \mathrm{Al}, \mathrm{C}$ and $\mathrm{B}$ in appropriate nuclide composition. Randomly distributed sources in this region increased particle emission and reaction rate in the entire MCNP geometry thus expediting statistical sampling for tallies. Core peripheral fillers and their surrounding coolant were simulated by an $\mathrm{Al}-\mathrm{H}_{2} \mathrm{O}$ filled cylindrical shell, which was enclosed within an aluminum pressure vessel wall. To properly simulate the homogenized critical core under different operational conditions, the weight percentage of the nuclides in the model input had to be adjusted according to the recorded fuel inventory and critical rod bank position.

For the shutter-closed case, the BMRR basic design feature of $\mathrm{K}_{\text {eff }}=1$ shown in the graphite reflected critical assembly alone ( $1.7 \mathrm{~m}$ cube) was utilized for the source term check-up. Criticality calculations using the shutter-opened configuration were also performed in order to compare the computed thermal neutron flux with the measured flux at the core-shutter interfacial air gap. In the air gap, a significant portion of the neutron flux has already been thermalized, so that the downstream neutron beam has a low intensity of epithermal neutrons. This prompted the design and installation of the fission converter to convert these thermal neutrons into a fission source of fast neutrons, which could be moderated to epithermal energies downstream.

Using the flux and dose tallies obtained at the shutter apex along the beam centerline, the design of the fission converter, including its inside plates' arrangement and cooling plus ${ }^{235} \mathrm{U}$ loading, was evaluated jointly with the design of the down beam moderator assembly. The installation of two assemblies in series was found crucial in producing both a highly intensified and forward directed (current to flux ratio) epithermal neutron beam. The moderator assembly consisted of $2.56 \mathrm{~cm}$ aluminum plates that were welded along their edges to form a straight rectangular box with ends opened to the neutrons to aid streaming of the beam. Materials tested for fast neutron moderation were $\mathrm{Al}_{-} \mathrm{Al}_{2} \mathrm{O}_{3}$ and $\mathrm{Al}-\mathrm{AlF}_{3}$ in repeated double layers within the aluminum box. To focus scattering of fast neutrons within the $45 \mathrm{~cm}$ long assembly, the box was wrapped with a $0.6 \mathrm{~cm}$ polyethylene sheet. To reduce streaming of thermal neutrons through the material layers, a $0.5 \mathrm{~mm}$ thick cadmium film was attached to the far side of the shutter moderator assembly. The beam quality (dose level) was significantly improved by reconfiguring the shielding of fast neutrons (concrete, $\mathrm{Al}$ ), thermal neutrons ( $\mathrm{Cd})$, prompt gamma rays $(\mathrm{Bi}, \mathrm{Pb}$ ) and secondary gamma rays $(\mathrm{Pb})$ along the beam pathway to the irradiation port. To eliminate stray neutrons and gamma rays, an additional $10 \mathrm{~cm}^{6} \mathrm{Li}$-enriched poly-slab was used as the outer wall of the beam 
line facility, which was also the inner wall of the ENIF. Mounting a $15 \mathrm{~cm}$ long ${ }^{6} \mathrm{Li}$-poly collimator on the port central $20 \mathrm{~cm}$ cube cavity, the beam path ended at the collimator face would be lengthened by $10 \mathrm{~cm}$, yielding a higher focused beam for patient treatment.

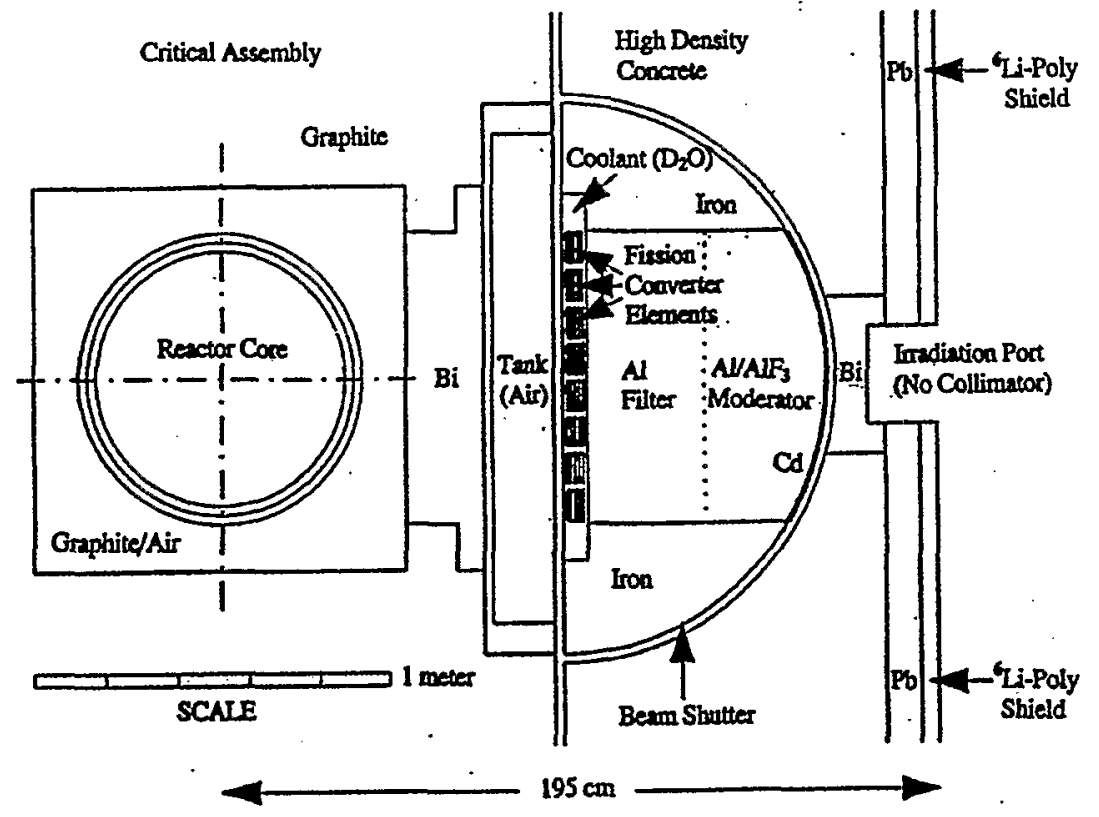

Figure 1. The optimum design of the BMRR epithermal neutron beam line used for the BNCT

Dose measurements using cadmium-covered $12 \mathrm{mg}$ gold foils $(0.013 \mathrm{~mm})$ were conducted at the beam line air gap, the critical assembly boundary, to validate the thermal flux calculated by the code. Measurements were also performed using ${ }^{6} \mathrm{LiF}$ and ${ }^{7} \mathrm{LiF}$ thermoluminescent dosimeters (TLD) at the beam port and several other locations within the patient treatment room, both with and without the patient in place. There was good agreement between the TLD data and the MCNP results for gamma-ray dose, but a discrepancy for neutron dose rate. This discrepancy was later confirmed from evidence of neutron absorption by the brain tissue and tumor cells of patient (a preferred situation for the BNCT). When a Lucite head phantom was used for model setup and irradiation testing, a closer match of neutron dose rate was obtained, whereas a larger gamma-ray absorption in the phantom than at the patient was found. It was also noted that neutron and gamma-ray dose rates fell off rapidly as the distance increased from the beam centerline. For the empty room with no patient present, then was a reduction in the neutron dose rate at the port face by a factor of 5-10 in all directions at a distance of $0.6 \mathrm{~m}$ from the beam center, compared to the collimator center results. There was a similar reduction of 10 to 30 in the gamma-ray dose rate. Those reduction factors of radiation that characterized the BMRR epithermal neutron beam at the irradiation port were used as the safety guideline for patient treatment and worker protection.

\section{Converter Design}

In 1994, the BMRR fission converter conceptual design was initiated using fission fuel plates as a neutron source to enhance the epithermal neutron flux intensity at the epithermal beam port in the BMRR. MCNP calculations, using different converter configurations, were used to verify the neutron flux enhancement at various beam port locations. These calculations also confirmed that after long duty cycles for the BNCT Phase II studies (for example, 8 hours per day including the weekends) the decay gamma rays were the major source of heating on the fission plates. In 1999, a 
new neutron moderator material, FLUENTAL ${ }^{\mathrm{TM}}\left(\mathrm{Al} / \mathrm{Al}^{-\mathrm{AlF}_{3}}\right.$ [4]) was successfully developed and was tested as a moderator at BMRR as part of major effort to upgrade the shutter. This effort involved a combination of various configurations that included three different types of fuel plates (Table 1), three cooling materials (air, $\mathrm{D}_{2} \mathrm{O}, \mathrm{H}_{2} \mathrm{O}$ ), and a variety of neutron moderator materials.

Table 1. Dimensions, ${ }^{235} \mathrm{U}$ loadings, and enrichments of the plates proposed for the converter design

\begin{tabular}{|l|c|c|c|}
\hline $\begin{array}{l}\text { Plates } \\
\text { (type) }\end{array}$ & $\begin{array}{c}\text { Full Dimension (t } \times \text { L } \times \text { W) } \\
\text { (U-metal and claddings) }\end{array}$ & $\begin{array}{c}\text { Gram of }{ }^{235} \text { U per Plate } \\
\text { (condition) }\end{array}$ & $\begin{array}{c}\text { Plate Enrichment } \\
\text { (LEU vs. HEU) }\end{array}$ \\
\hline $\begin{array}{l}\text { Argonne } \\
\text { (Janus) }\end{array}$ & $\begin{array}{c}0.3 \mathrm{~cm} \times 10.16 \mathrm{~cm} \times 102 \mathrm{~cm} \\
\text { (U metal, Steel-clad) }\end{array}$ & $\begin{array}{c}1,000 \\
\text { (slightly irradiated) }\end{array}$ & $\begin{array}{c}19.75 \%{ }^{235} \mathrm{U} \\
\text { (LEU) }\end{array}$ \\
\hline $\begin{array}{l}\text { HFBR } \\
\text { (KM) }\end{array}$ & $\begin{array}{c}0.127 \mathrm{~cm} \times 5.72 \mathrm{~cm} \times 58 \mathrm{~cm} \\
\left(\mathrm{U}_{3} \mathrm{O}_{8} \text {-Al cermet, Al-clad) }\right.\end{array}$ & $\begin{array}{c}19.5 \\
\text { (fresh) }\end{array}$ & $93 \%{ }^{235} \mathrm{U}$ \\
BMRR & $\begin{array}{c}0.1524 \mathrm{~cm} \times 6.35 \mathrm{~cm} \times 61 \mathrm{~cm} \\
\text { BMRU }\end{array}$ \\
(A) & (U-Al metal, Al-clad) & 7.78 & $93 \%{ }^{235} \mathrm{U}$ \\
(fresh) & $(\mathrm{HEU})$ \\
\hline
\end{tabular}

The fuel plates used at the BMRR and the High Flux Beam Reactor (HFBR) at BNL were high enrichment ${ }^{235} \mathrm{U}$ (HEU) plates (i.e., $>80$ weight $\%$ of ${ }^{235} \mathrm{U}$ in the total uranium), for which a nuclear safeguards limitation allowed no more than 2 kilograms of ${ }^{235} U$ in the fuel. The integrity of these HEU plates had been proven from previous high power and long operating cycles in the BMRR and the HFBR. Ten low enrichment uranium (LEU) plates (i.e., $<20$ weight $\%$ of ${ }^{235} U$ in total uranium) from the decommissioned Janus Reactor at the Argonne National Laboratory (ANL) were obtained as a backup because of the $2 \mathrm{~kg}$ safeguards restriction.

Assuming a $3 \mathrm{MW}$ power level, MCNP calculated the integral flux of the epithermal neutron beam at the stainless-steel moving wall (shutter boundary), the bismuth outer surface, and the center opening of the outer ${ }^{6} \mathrm{Li}$-poly shield. Foils were placed at the center of the bismuth surface for measurement and calibrations. 8 Janus plates $(8 \times 10.16 \mathrm{~cm})$ in a single array approximated either 14 HFBR type KM plates $(14.2 \times 5.72 \mathrm{~cm})$ or 12 BMRR type A plates $(12.8 \times 6.35 \mathrm{~cm})$, where $10.16 \mathrm{~cm}, 5.72 \mathrm{~cm}$ and $6.35 \mathrm{~cm}$ represent the actual width of the fueled region for the Janus, the HFBR, and the BMRR plates, respectively. Table 2 lists the flux tallies obtained from a $5 \mathrm{~cm}-$ dia. circle, where the epithermal neutron energy at BMRR was between $0.4 \mathrm{eV}$ and $10 \mathrm{keV}$.

Table 2. Beam port epithermal neutron flux obtained from different plates-coolant in converter

\begin{tabular}{|c|c|c|c|c|c|c|}
\hline \multirow[t]{2}{*}{ Cases } & \multirow[t]{2}{*}{ Plates } & \multirow[t]{2}{*}{ Coolant } & \multirow{2}{*}{$\begin{array}{c}\text { Total }{ }^{235} \mathrm{U} \\
\text { (gram) }\end{array}$} & \multicolumn{3}{|c|}{ Epithermal Neutron Flux ( $\left.\mathrm{n} / \mathrm{cm}^{2} / \mathrm{sec}\right)$} \\
\hline & & & & Wall & $\mathrm{Bi}$ & Port \\
\hline Base & none $\left(\mathrm{Al}_{2} \mathrm{O}_{3}\right)$ & no $\left(\mathrm{Al}_{2} \mathrm{O}_{3}\right)$ & 0. & 5.4E09 & $2.6 \mathrm{E} 09 *$ & $1.3 \mathrm{E} 09$ \\
\hline 1 & 8 Janus & $\mathrm{H}_{2} \mathrm{O}$ & 8,000 & 3.4E10 & $1.7 \mathrm{E} 10$ & 9.0E09 \\
\hline 2 & 8 Janus & $\mathrm{D}_{2} \mathrm{O}$ & 8,000 & 4.1E10 & $2.0 \mathrm{E} 10$ & $1.1 \mathrm{E} 10$ \\
\hline 3 & 8 Janus & Air & 8,000 & $4.5 \mathrm{E} 10$ & $2.2 \mathrm{E} 10$ & $1.2 \mathrm{E} 10$ \\
\hline 4 & 14 HFBR-KM & $\mathrm{H}_{2} \mathrm{O}$ & 277.3 & 8.4E09 & 4.2E09 & $2.2 \mathrm{E} 09$ \\
\hline 5 & 14 HFBR-KM & $\mathrm{D}_{2} \mathrm{O}$ & 277.3 & $1.1 \mathrm{E} 10$ & 5.3E09 & 2.7E09 \\
\hline 6 & 14 HFBR-KM & Air & 277.3 & $1.2 \mathrm{E} 10$ & $5.7 \mathrm{E} 09$ & $3.0 \mathrm{E} 09$ \\
\hline 7 & 12 BMRR-A & $\mathrm{H}_{2} \mathrm{O}$ & 99.58 & $5.5 \mathrm{E} 09$ & 2.8E09 & $1.5 \mathrm{E} 09$ \\
\hline 8 & 12 BMRR-A & $\mathrm{D}_{2} \mathrm{O}$ & 99.58 & $7.2 \mathrm{E} 09$ & $3.5 \mathrm{E} 09$ & $1.8 \mathrm{E} 09$ \\
\hline 9 & 12 BMRR-A & Air & 99.58 & $7.9 \mathrm{E} 09$ & 4.0E09 & $2.0 \mathrm{E} 09$ \\
\hline
\end{tabular}

(* Measured epithermal neutron flux at Bi surface of the shutter was $2.7 \times 10^{9} \mathrm{n} / \mathrm{cm}^{2} / \mathrm{sec}$ at $3 \mathrm{MW}$ )

Since deuterium has a much lower neutron absorption cross section than hydrogen, the cases 
in Table 2 indicate that the beam intensity is $20 \%$ higher using $\mathrm{D}_{2} \mathrm{O}$ as a coolant for the fission plates than using $\mathrm{H}_{2} \mathrm{O}$. When air is used as a coolant, there is a $10 \%$ gain in flux intensity but there were problems, e.g., the radioactivity of ${ }^{41} \mathrm{Ar}$ produced by neutron activation of argon in air ( $0.93 \%$ by volume), the problem of air leakage (the system could not be made leak tight), and difficulties in the accurate measurement of the amount of airflow required for cooling of the plates. As a result, air was eliminated as a coolant medium. Using $\mathrm{D}_{2} \mathrm{O}$ as the coolant, the calculated heating rate was $78 \mathrm{~kW}$ for the 8 Janus plates, $11.6 \mathrm{~kW}$ for the 14 HFBR-KM plates and $4.8 \mathrm{~kW}$ for the $12 \mathrm{BMRR}-\mathrm{A}$ plates, respectively. Thus, a multiple array of HFBR and BMRR plates or a simple array of HFBR and BMRR fuel elements could be used to increase the neutron beam intensity while keeping the heating rate below that generated from the 8 Janus plates.

\section{Comparison of Moderators in the Shutter}

MCNP was also used to optimize the beam flux for the moderator in the shutter, using different combinations of $\mathrm{Al}, \mathrm{Al}_{2} \mathrm{O}_{3}$, and $\mathrm{AlF}_{3}$ slabs. Three MCNP baseline cases were run without fission plates or coolant for these moderator slabs. Table 3 indicates that the increase in the epithermal neutron flux at the beam port is the largest when FLUENTAL ${ }^{\mathrm{TM}}\left(\mathrm{Al} / \mathrm{Al}-\mathrm{AlF}_{3}\right)$ is used as a moderator, regardless of the presence of fuel plates or coolant.

Table 3. Beam port epithermal flux obtained at $3 \mathrm{MW}$ from various filter/moderator in the shutter

\begin{tabular}{|c|c|c|c|c|c|}
\hline \multirow[t]{2}{*}{ No. of Plates } & \multirow[t]{2}{*}{ Coolant } & \multirow[t]{2}{*}{ Filter/Moderator } & \multicolumn{3}{|c|}{ Epithermal Neutron Flux $\left(\mathrm{n} / \mathrm{cm}^{2} / \mathrm{sec}\right)$} \\
\hline & & & Wall & $\mathrm{Bi}$ & Port \\
\hline none (base case) & no & $\mathrm{Al}_{2} \mathrm{O}_{3} / \mathrm{Al}-\mathrm{Al}_{2} \mathrm{O}_{3}$ & $5.4 \mathrm{E} 09$ & $2.6 \mathrm{E} 09$ & $1.3 \mathrm{E} 09$ \\
\hline none & no & $\mathrm{Al} / \mathrm{Al}-\mathrm{Al}_{2} \mathrm{O}_{3}$ & $3.2 \mathrm{E} 10$ & $6.4 \mathrm{E} 09$ & $3.5 \mathrm{E} 09$ \\
\hline None & no & $\mathrm{Al} / \mathrm{Al}-\mathrm{AlF}_{3}$ & $4.2 \mathrm{E} 10$ & 8.7E09 & 4.9E09 \\
\hline 8 Janus & $\mathrm{D}_{2} \mathrm{O}$ & $\mathrm{Al}_{2} \mathrm{O}_{3} / \mathrm{Al}-\mathrm{Al}_{2} \mathrm{O}_{3}$ & 4.1E10 & $2.0 \mathrm{E} 10$ & $1.1 \mathrm{E} 10$ \\
\hline 8 Janus & $\mathrm{D}_{2} \mathrm{O}$ & $\mathrm{Al} / \mathrm{Al}-\mathrm{Al}_{2} \mathrm{O}_{3}$ & $1.5 \mathrm{E} 10$ & 2.9E10 & $1.6 \mathrm{E} 10$ \\
\hline 8 Janus & $\mathrm{D}_{2} \mathrm{O}$ & $\mathrm{Al} / \mathrm{Al}-\mathrm{AlF}_{3}$ & 1.7E11 & $3.6 \mathrm{E} 10$ & 2.1E10 \\
\hline 14 HFBR-KM & $\mathrm{D}_{2} \mathrm{O}$ & $\mathrm{Al}_{2} \mathrm{O}_{3} / \mathrm{Al}_{-\mathrm{Al}_{2} \mathrm{O}_{3}}$ & $1.1 \mathrm{E} 10$ & $5.3 \mathrm{E} 09$ & $2.7 \mathrm{E} 09$ \\
\hline 14 HFBR-KM & $\mathrm{D}_{2} \mathrm{O}$ & $\mathrm{Al} / \mathrm{Al}-\mathrm{Al}_{2} \mathrm{O}_{3}$ & $4.8 \mathrm{E} 10$ & 8.7E09 & $4.8 \mathrm{E} 09$ \\
\hline 14 HFBR-KM & $\mathrm{D}_{2} \mathrm{O}$ & $\mathrm{Al} / \mathrm{Al}-\mathrm{AlF}_{3}$ & $6.4 \mathrm{E} 10$ & $1.2 \mathrm{E} 10$ & $7.2 \mathrm{E} 09$ \\
\hline 12 BMRR-A & $\mathrm{D}_{2} \mathrm{O}$ & $\mathrm{Al}_{2} \mathrm{O}_{3} / \mathrm{Al}-\mathrm{Al}_{2} \mathrm{O}_{3}$ & $7.2 \mathrm{E} 09$ & $3.5 \mathrm{E} 09$ & $1.8 \mathrm{E} 09$ \\
\hline 12 BMRR-A & $\mathrm{D}_{2} \mathrm{O}$ & $\mathrm{Al} / \mathrm{Al}-\mathrm{Al}_{2} \mathrm{O}_{3}$ & $3.8 \mathrm{E} 10$ & $6.9 \mathrm{E} 09$ & $3.8 \mathrm{E} 09$ \\
\hline 12 BMRR-A & $\mathrm{D}_{2} \mathrm{O}$ & $\mathrm{Al} / \mathrm{Al}-\mathrm{AlF}_{3}$ & $4.8 \mathrm{E} 10$ & 8.8E09 & $5.0 \mathrm{E} 09$ \\
\hline
\end{tabular}

\section{Geometry of the Shutter Window}

A converging window to hold the neutron moderator produced forward-directed neutron beams. The calculated current/flux ratio of the epithermal neutrons, $\mathrm{J}_{\mathrm{cpi}} / \phi_{\mathrm{cpi}}$ (beam orientation), at the irradiation location was about 0.67 , when a moderator was not used. When the reconfigured core followed by a fission converter along the beam line, the shutter box was redesigned with a straight window $(100 \mathrm{~cm} \times 60 \mathrm{~cm})$ in shutter that extended from the converter down to the shutter's moving boundary. This increases the beam path in the moderator to effectively slow down the fast neutrons. To moderate more of the fission neutrons from the converter, the front opening of the window was designed to match the full width of the fission plates, which had been placed side by side vertically to the beam path. To confine any scattered neutrons and gamma rays within the window boundary, a doubled layer box of aluminum plates $(2.54 \mathrm{~cm})$ covered with polyethylene sheets $(0.6 \mathrm{~cm})$ was used. The neutron and gamma-ray shielding layers $(0.5 \mathrm{~mm} \mathrm{Cd}$ 
and $11 \mathrm{~cm} \mathrm{Bi}$ ) that originally resided between the moderator window and shutter aperture were relocated to the stationary position outside of the shutter's moving boundary. As a result, higher beam focusing $\left(\mathrm{J}_{\text {ep }} / \phi_{\text {epi }}\right.$ from 0.67 to 0.72$)$ and lower beam dose rate (33\% for fast neutrons and $25 \%$ for gamma rays) were obtained at the irradiation port. For comparison, beam intensity calculated for 2 moderator geometries with $\mathrm{Al}_{2} \mathrm{O}_{3}$ and with FLUENTAL ${ }^{\mathrm{TM}}$ is listed in Table 4.

Table 4. Beam port epithermal neutron flux obtained at $3 \mathrm{MW}$ from 2 window geometries at shutter

\begin{tabular}{|c|c|c|c|c|c|c|}
\hline \multirow[t]{2}{*}{ Plates } & \multirow[t]{2}{*}{ Window } & \multirow[t]{2}{*}{ Coolant } & \multirow[t]{2}{*}{ Filter/Moderator } & \multicolumn{3}{|c|}{ Epithermal Neutron Flux (n/cm $/ \mathrm{sec})$} \\
\hline & & & & Wall & $\mathrm{Bi}$ & Port \\
\hline none & converging & no & $\mathrm{Al} / \mathrm{Al}-\mathrm{Al}_{2} \mathrm{O}_{3}$ & $3.2 \mathrm{E} 10$ & $6.4 \mathrm{E} 09$ & $3.5 \mathrm{E} 09$ \\
\hline none & converging & no & $\mathrm{Al} / \mathrm{Al}-\mathrm{AlF}_{3}$ & $4.2 \mathrm{E} 10$ & $8.7 \mathrm{E} 09$ & 4.9E09 \\
\hline none & straight & no & $\mathrm{Al} / \mathrm{Al}-\mathrm{Al}_{2} \mathrm{O}_{3}$ & $3.9 \mathrm{E} 10$ & 7.0E09 & 3.9E09 \\
\hline none & straight & no & $\mathrm{Al} / \mathrm{Al}-\mathrm{AlF}_{3}$ & 5.7E10 & $1.1 \mathrm{E} 10$ & $6.0 \mathrm{E} 09$ \\
\hline 8 Janus & converging & $\mathrm{D}_{2} \mathrm{O}$ & $\mathrm{Al} / \mathrm{Al}-\mathrm{Al}_{2} \mathrm{O}_{3}$ & $1.5 \mathrm{E} 11$ & $2.9 \mathrm{E} 10$ & $1.6 \mathrm{E} 10$ \\
\hline 8 Janus & converging & $\mathrm{D}_{2} \mathrm{O}$ & $\mathrm{Al}-\mathrm{Al}-\mathrm{AlF}_{3}$ & 1.7E11 & $3.6 \mathrm{E} 10$ & 2.1E10 \\
\hline 8 Janus & straight & $\mathrm{D}_{2} \mathrm{O}$ & $\mathrm{Al} / \mathrm{Al}-\mathrm{Al}_{2} \mathrm{O}_{3}$ & 1.7E11 & 3.3E10 & $1.8 \mathrm{E} 10$ \\
\hline 8 Janus & straight & $\mathrm{D}_{2} \mathrm{O}$ & $\mathrm{Al} / \mathrm{Al}-\mathrm{AlF}_{3}$ & $2.0 \mathrm{E} 11$ & 4.3E10 & $2.6 \mathrm{E} 10$ \\
\hline 14 HFBR & converging & $\mathrm{D}_{2} \mathrm{O}$ & $\mathrm{Al} / \mathrm{Al}-\mathrm{Al}_{2} \mathrm{O}_{3}$ & $4.8 \mathrm{E} 10$ & 8.7E09 & $4.8 \mathrm{E} 09$ \\
\hline 14 HFBR & converging & $\mathrm{D}_{2} \mathrm{O}$ & $\mathrm{Al} / \mathrm{Al}-\mathrm{AlF}_{3}$ & $6.4 \mathrm{E} 10$ & $1.2 \mathrm{E} 10$ & $7.2 \mathrm{E} 09$ \\
\hline 14 HFBR & straight & $\mathrm{D}_{2} \mathrm{O}$ & $\mathrm{Al} / \mathrm{Al}-\mathrm{Al}_{2} \mathrm{O}_{3}$ & $5.4 \mathrm{E} 10$ & 1.0E10 & $5.6 \mathrm{E} 09$ \\
\hline $14 \mathrm{HFBR}$ & straight & $\mathrm{D}_{2} \mathrm{O}$ & $\mathrm{Al} / \mathrm{Al}-\mathrm{AlF}_{3}$ & $7.3 \mathrm{E} 10$ & $1.5 \mathrm{E} 10$ & $8.5 \mathrm{E} 09$ \\
\hline $12 \mathrm{BMRR}$ & converging & $\mathrm{D}_{2} \mathrm{O}$ & $\mathrm{Al} / \mathrm{Al}-\mathrm{Al}_{2} \mathrm{O}_{3}$ & $3.8 \mathrm{E} 10$ & $6.9 \mathrm{E} 09$ & $3.8 \mathrm{E} 09$ \\
\hline $12 \mathrm{BMRR}$ & converging & $\mathrm{D}_{2} \mathrm{O}$ & $\mathrm{Al} / \mathrm{Al}-\mathrm{AlF}_{3}$ & $4.8 \mathrm{E} 10$ & $8.8 \mathrm{E} 09$ & $5.0 \mathrm{E} 09$ \\
\hline 12 BMRR & straight & $\mathrm{D}_{2} \mathrm{O}$ & $\mathrm{Al} / \mathrm{Al}-\mathrm{Al}_{2} \mathrm{O}_{3}$ & $4.3 \mathrm{E} 10$ & $8.2 \mathrm{E} 09$ & 4.4E09 \\
\hline 12 BMRR & straight & $\mathrm{D}_{2} \mathrm{O}$ & $\mathrm{Al} / \mathrm{Al}-\mathrm{AlF}_{3}$ & $6.0 \mathrm{E} 10$ & $1.2 \mathrm{E} 10$ & 6.7E09 \\
\hline
\end{tabular}

\section{Optimum Beam Design}

In meeting the $2 \mathrm{~kg}$ limit on ${ }^{235} \mathrm{U}$ loaded in HEU fission plates, the highest beam intensity at the irradiation port was $1.9 \times 10^{10} \mathrm{n}_{\text {epi }} / \mathrm{cm}^{2} / \mathrm{sec}$, corresponding to the use of 8 fresh HFBR plates or 18 fresh BMRR plates arranged in each of the 12 elements in a single array across the beam centerline. The total loading of ${ }^{235} \mathrm{U}$ corresponded to $1.87 \mathrm{~kg}$ and $1.68 \mathrm{~kg}$ in 12 HFBR partial elements and 12 BMRR full elements, respectively. Although the total heating rate on the 12 BMRR elements $(63 \mathrm{~kW})$ was about $10 \%$ higher than that on the 12 HFBR elements $(57 \mathrm{~kW})$, the highest heating rate per plate $(0.52 \mathrm{~kW})$ in the BMRR elements was only about $55 \%$ of that in the HFBR elements $(0.94 \mathrm{~kW})$. The critical heating rate calculated under different cooling conditions was much higher than these values [5], so the integrity of the HFBR and BMRR plates in assembled elements would be maintained even after a long duty cycle. In Table 5, results from two MCNP runs that yielded the same epithermal neutron intensity at the irradiation port's ${ }^{6} \mathrm{Li}$ poly surface were presented. The fast neutron dose and gamma-ray dose per epithermal neutron were also calculated by using the optional heating tallies in the model, where energy deposition in a tissue-equivalent material $(\mathrm{H}, \mathrm{C}, \mathrm{N}, \mathrm{O})$ was obtained from a thin cell $(1 \mathrm{~cm}$ thick, $10 \mathrm{~cm}$ in diameter) placed at the port face center location. This represent an approximate design version for the optimized beam line, where the neutron fraction in the epithermal energy range $(0.4 \mathrm{eV}<\mathrm{E}<10$ $\mathrm{keV}$ ) had been improved to $91 \%$ of the total neutrons in the entire energy spectrum, whereas thermal neutrons $(\mathrm{E}<0.4 \mathrm{eV}$ ) had been reduced to $4 \%$ of the total neutrons reaching the beam port. When the collimator was not mounted on the port cavity, the beam orientation $\left(J_{\text {epi }} / \phi_{\text {epi }}\right)$ of the epithermal neutrons was 0.72 , a $7 \%$ improvement. 
Table 5. Beam intensity, total heating rate, current-to-flux ratio, and beam dose at irradiation port

\begin{tabular}{|c|c|c|c|c|c|c|c|}
\hline \multirow{2}{*}{$\begin{array}{l}\text { Plates in } 12 \\
\text { Elements } \\
\text { (each) }\end{array}$} & \multicolumn{3}{|c|}{ 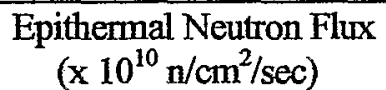 } & \multirow[t]{2}{*}{$\begin{array}{l}\text { Total Heating } \\
(\mathrm{kW})\end{array}$} & \multirow[t]{2}{*}{$\mathrm{J}_{\mathrm{ep}} / \phi_{\mathrm{cpi}}$} & \multicolumn{2}{|c|}{ 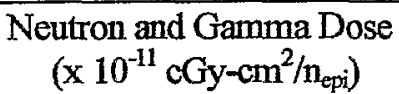 } \\
\hline & Wall & $\mathrm{Bi}$ & Port & & & Fast Neutrons* & Gamma \\
\hline 8 HFBR & 17 & 3.2 & 1.9 & 57 & 0.72 & 3.3 & 1.4 \\
\hline 18 BMRR & 18 & 3.3 & 1.9 & 63 & 0.72 & 3.6 & 1.3 \\
\hline
\end{tabular}

(* Fast neutron dose was computed from energy deposition of all neutrons at energy $<20 \mathrm{MeV}$ )

\section{Conclusions}

We presented a conceptual design of the BMRR epithermal shutter that optimizes the neutron beam for BNCT. The design relied on Monte Carlo calculations to predict neutron and gammaray fluxes and dose rates along the beam path downstream of the encapsulated fission converter plates. Geometry reconfiguration and material replacement in the shutter assembly provided the highest epithermal neutron flux and orientation (current to flux ratio) with the lowest fast neutron dose and gamma-ray dose at beam port locations. Dose measurements at the core-shutter interface and at the patient's irradiation port benchmarked the computational model of the Monte Carlo MCNP code. Different types of HEU and LEU fuel plates were evaluated for the converter design to meet the $2 \mathrm{~kg}$ safeguard limit for the total ${ }^{235} \mathrm{U}$ loading in the HEU fuel by using the decay gamma-ray heating and the epithermal neutron intensity.

The maximum epithermal flux produced by the $\mathrm{D}_{2} \mathrm{O}$ cooled fission converter that contained 8 HFBR or 18 BMRR plates (HEU fuel) in each of 12 elements in a single array across the beam path was $1.9 \times 10^{10} \mathrm{n}_{\text {epi }} / \mathrm{cm}^{2} / \mathrm{sec}$, obtained at the center of the external face of the beam port. This flux was 14 times greater than the flux generated in the reactor core $\left(1.3 \times 10^{9} \mathrm{n}_{\mathrm{cp}} / \mathrm{cm}^{2}-\mathrm{sec}\right)$ without the fission converter. The fast neutron dose and the gamma-ray dose were $3.3 \times 10^{-11} \mathrm{cGy}-\mathrm{cm}^{2} / \mathrm{n}_{\text {epi }}$ and $1.4 \times 10^{-11} \mathrm{cGy}-\mathrm{cm}^{2} / \mathrm{n}_{\text {epi }}$, respectively, at the port aperture, with HFBR plates and $\mathrm{Al} / \mathrm{Al}-\mathrm{AlF}_{3}$ $\left(\right.$ FLUENTAL $^{\mathrm{TM}}$ ). Without the collimator on the port aperture in the treatmentroom, the estimated current to flux ratio of the epithermal neutrons was 0.72 at the center of the port location, a $7 \%$ improvement. The decay gamma-ray heating on the HFBR plates ( 8 by 12 plates containing 1.87 $\mathrm{kg}^{235} \mathrm{U}$ ) was $57 \mathrm{~kW}$, far below the critical heating value, eliminating safety concerns and duty cycle problems. When the BMRR plates were used (18 by 12 plates containing $1.68 \mathrm{~kg}^{235} \mathrm{U}$ ), similar results were obtained providing an alternative for the shutter design.

\section{Acknowledgement}

This research was supported by the US-DOE under the contract DE-AC02-98CH10886.

\section{References}

[1] J. B. Godel, Description of Facilities and Mechanical Components - Medical ResearchReactor (MRR), BNL-600 (1960).

[2] A. D. Chanana, et al., "Boron Neutron Capture Therapy for Glioblastoma Multiforme: Interim Results from Phase I/II Dose Escalation Studies", Neurosurgery, 44, p.1182 (1999).

[3] US-DOE/LANL, MCNP 4B2 - Monte Carlo N-Particle Transport Code System (1997).

[4] T. Seren, et al., "Neutron Beam Characterization at the Finnish BNCT Facility", Reactor Dosimetry, Radiation Metrology and Assessment, ASTM-STP-1398, p.175 (1999).

[5] J. P. Hu, "Power Density Distribution in 8 Fission Converter Plates when the Shutter of Modified Epithermal Neutron Beam is Opened", BNL Memorandum (1996). 